DOI https://doi.org/10.30525/978-9934-588-80-8-1.39

\title{
ЗЦІЛЕННЯ МИСТЕЦТВОМ, АБО АРТ-ТЕРАПІЯ ЯК НАПРЯМОК ПСИХОЛОГІЧНОЇ КОРЕКЦІЇ ТА РОЗВИТКУ ОСОБИСТОСТІ
}

\author{
Радько О. В. \\ кандидат психологічних наук, \\ дочент кафедри психології та педагогіки \\ Харківська державна академія культури \\ м. Харків, Украӥна
}

В останні роки, в освітніх і соціальних установах все частіше почали застосовувати такий інноваційний, здоров'я зберігаючий підхід, як психотерапія мистецтвом - арт-терапія.

Згідно із загальноприйнятим міжнародним визначенням, арт-терапія $\epsilon$ одним 3 напрямків креативної терапії мистецтвом, включаючи такі напрями, як музична терапія, танцювально-рухова терапія і драматерапія. Всі вони використовують творчу активність клієнтів як фактор лікувально-профілактичного впливу, але 3 переважною опорою на одну 3 модальностей, за допомогою якої клієнти творчо виражають себе [1, стор. 6].

Креативність - це засіб особистісного зростання, саморозуміння і відновлення. Створення художніх продуктів не тільки допомагає розкрити творчий потенціал особистості, але і поліпшити здоров'я та самопочуття.

Основними підходами, які вплинули на розвиток і становлення арттерапії, як окремого напрямку психотерапії, є:

- Психодинамічний підхід, який бере свій початок в працях 3. Фрейда і К. Юнга, наполягає на тому, що продукт художньої діяльності $\epsilon$ вираженням неусвідомлюваних психічних процесів. За словами представників даного напрямку, в арт-терапії кожна людина здатна виражати свої внутрішні конфлікти в візуальних формах, отримуючи таким чином доступ до глибинних почуттів і переживань, витісненим у несвідоме.

- Гуманістичний підхід в арт-терапії базується на уявленнях про креативність як внутрішній психічний ресурс особистості, який присутній постійно і розвиток якого дозволяє особистості успішно виступати в соціальній, міжособистісній та інших сферах. Цей напрямок центрировано на клієнті, а завдання всіх методик - наближення людини 
до його ідеального «Я», до повноцінно функціонуючої, цілісної творчої людини.

- Феноменологический підхід дотримується уявлень про те, що клієнт в арт-терапевтичному процесі шукає i знаходить спосіб вирішення своїх життєвих труднощів. В даному підході створення художнього твору в стані творчого натхнення трактується як змінений стан свідомості і прогресивний адаптаційний механізм. Переживання цього досвіду веде до здатності клієнта по-новому бачити і відчувати себе у внутрішньому і зовнішньому світах.

Всі розглянуті підходи сходяться в єдиній думці про те, що здатність до творчості є універсальною характеристикою людини, i кожна людина від природи здатна творити.

Аналізуючи потенціал арт-терапії та художньої діяльності, можна сформулювати функції даного напрямку:

1. Діагностична. Виявлення індивідуальної картини світу, вивчення неусвідомлюваних або приховуваних потреб, відображення емоційних переживань, діагностика труднощів клієнта, тощо.

2. Комунікативна. Міжособистісне спілкування і засвоєння загально-людських соціально-культурних цінностей.

3. Регуляторна. Зниження втоми, напруги, рівня стресу, негативних переживань.

4. Когнітивна. Усвідомлення себе, прихованих мотивів своїх дій, активне використання фантазії, реалізація творчих здібностей, отримання емоційного досвіду, розвиток духовно-моральної сфери особистості та інше.

5. Розвиваюча. Особистісний ріст, зростання соціальної компетентності, поліпшення комунікативної компетентності.

На сучасному етапі розвитку, арт-терапія являє собою не один, а кілька методів, як правило, пов'язаних з різними теоріями особистості, різними способами творчої активності клієнтів і моделями психотерапевтичної взаємодії. На наш погляд, маючи в своєму розпорядженні широким арсенал універсальних і специфічних прийомів лікувально-профілактичного впливу, арт-терапія виявляється високоефективна там, де більшість форм психотерапевтичної допомоги виявляються неприйнятними або малоефективними, наприклад, при роботі з дітьми з аутизмом, особами похилого віку.

На думку I. Сусаніна, арт-терапія володіє всіма п'ятьма основними ефектами, яким повинна відповідати будь-яка успішна психотерапія, $\mathrm{i}$ які були сформульовані в 1974 р Д. Франком. А саме:

1. Арт-терапія $\epsilon$ потужним і ефективним форматом для навчання, вона допомагає побачити перспективи в будь-який невизначеній 150 
ситуації, пропонує стимулюючі методи для засвоєння i запам'ятовування.

2. Як і інші терапії, арт-терапія вселяє надію на порятунок від душевних страждань. Віра в можливість відчувати себе краще є найпершим кроком у досягненні терапевтичного ефекту.

3. Арт-терапія являє собою досвід успішної діяльності так як створення будь-якого творчого продукту саме по собі несе почуття задоволеності.

4. Арт-терапія надає людині можливість контакту з іншими людьми. Почуття «бути зрозумілим» $\epsilon$ одним 3 найбільш сильних в арттерапевтичному процесі, так само як і фраза «я розумію» резонує через всі великі твори.

5. Художні образи в живопису, музиці, драматичному мистецтві викликають сильні емоції, такі, як любов, ненависть, наснага, страх. Ті глибокі зміни, які являються метою в арт-терапевтичному процесі, можуть статися лише якщо відтворити ці почуття, зрозуміти і прийняти ïx [3, стор. 10].

Таким чином, арт-терапія $є$ новим потужним психологічним напрямком корекції і розвитку особистості. I підтримуючи точку зору одного з провідних фахівців в області арт-терапії в Україні О. Тараріної, вважаємо, що мета арт-терапії - це розвиток збалансованої особистості, яка може тримати рівновагу між полярностями: любов - ненависть, слабкість - сила, самітність - близькість, кооперація - змагання, залежність - незалежність, домінування - підпорядкування, надія - відчай тощо [2, стор. 3].

\section{Література:}

1. Нормативный документ по регулированию профессиональной психотерапевтической и психологической деятельности в сфере арттерапии (арт-психотерапии). Стандарт профессиональной психотерапевтической (психологической) помощи в сфере арт-терапии (артпсихотерапии) / под общ. ред. Копытина А.И. - Санкт-ПетербургМосква: 2018. - 100 с.

2. «Практикум по арт-терапии : шкатулка мастера : науч.-метод, пособ. / Тарарина Е. - К. : АСТАМИР-В, 2016. : Астамир-В; Киев; 2016. $-101 \mathrm{c}$.

3. Сусанина И. В. «Введение в арт-терапию». Из-во: Когито-Центр, 2007. - 95 стр. 